\title{
Bruk av språk og diskusjoner for å fremme elevers forståelse i kvantefysikk gjennom digitale ressurser
}

\author{
Berit Bungum $^{1 \star}$ og Cathrine Wahlstrøm Tellefsen, ${ }^{2}$ \\ ${ }^{1}$ Skolelaboratoriet for matematikk, naturfag og teknologi, Program for lererutdanning, \\ NTNU, Trondheim, Norge; ${ }^{2}$ Fysisk Institutt, Universitetet $i$ Oslo, Norge
}

\begin{abstract}
Sammendrag
I prosjektet ReleKvant utvikler vi nettbaserte læringsressurser for moderne fysikk og undersøker elevenes læringsprosesser gjennom «Educational Design Research». Ressursene er tilpasset læreplanen for fysikk programfag i norsk videregående skole. De er utviklet med utgangspunkt i et sosiokulturelt syn på læring, og vektlegger elevenes bruk av språket. I denne artikkelen undersøker vi hvordan elevene forstår to grunnleggende prinsipper i kvantefysikk, kvantisering og bølge-partikkeldualismen for lys, og hvordan elevers bruk av kvalitativt skriftlig språk og gruppediskusjoner kan bidra til å utvikle deres forståelse. Datamateriale er samlet fra sju fysikk-klasser ved fem ulike skoler som deltar i ReleKvant-prosjektet. Resultatene avdekker en rekke misoppfatninger blant elevene, og de viser hvordan elevers bruk av språk er viktig for å bringe disse misoppfatningene fram i dagen. Imidlertid finner vi at verdien av elevdiskusjoner kan være begrenset dersom lærerens stemme ikke er representert som en faglig autoritet i kommunikasjonen, og vi peker på faglig sett kritiske punkter hvor læreren bør bidra for å støtte elevenes læring. Vi dokumenterer også hvordan resultatene har bidratt til å videreutvikle undervisningsressursene for å styrke elevenes læring i kvantefysikk.
\end{abstract}

Nøkkelord: kvantefysikk; filosofi; språk; digitale laringsressurser

\begin{abstract}
In the project ReleQuant, we develop digital teaching resources for modern physics in upper secondary schools in Norway, and investigate students' learning processes by means of Educational Design Research. The resources are developed within a sociocultural view of learning, and emphasise students' use of language. In this paper we investigate how students understand two key principles in quantum physics, quantization and the wave-particle duality, and how students' use of qualitative written language and peer discussions contribute to deepening their understanding of these principles. Data material is gathered from seven physics classes at five different schools. The results expose a number of misconceptions among students, and show that the use of language is important in order to reveal these misconceptions. However, if the authoritative voice of the teacher is not represented, the value of the discussions in developing students' conceptions may be limited. Based on these results, we point to critical points where teachers should intervene with students in
\end{abstract}

^Korrespondanse: Berit Bungum, Skolelaboratoriet, NTNU, Høgskoleringen 5, 7491 Trondheim, E-post: berit.bungum@ntnu.no

(C)2016 Berit Bungum og Cathrine Wahlstrøm Tellefsen. This is an Open Access article distributed under the terms of the Creative Commons Attribution 4.0 International License (http://creativecommons.org/licenses/by/4.0/), allowing third parties to copy and redistribute the material in any medium or format and to remix, transform, and build upon the material for any purpose, even commercially, provided the original work is properly cited and states its license.

Citation: Berit Bungum og Cathrine Wahlstrom Tellefsen. «Bruk av språk og diskusjoner for å fremme elevers forståelse $i$ kvantefysikk gjennom digitale ressurser.» Nordisk tidsskrift for pedagogikk og kritikk, Vol. 2, 2016, pp. 2-16. http://dx.doi.org/10.17585/ntpk.v2.127 
order to support their learning. We also document how the results have led to improvements in the teaching resources.

Keywords: quantum physics; philosophy; language; digital learning resources

Received: September 2015; Accepted: January 2016; Published: April 2016

\section{Introduksjon}

Kvantefysikk og relativitetsteori bryter fundamentalt med vår erfaring med den fysiske verden og hvordan den beskrives i klassisk fysikk. Undersøkelser har vist at disse temaene, og deres betydning for vårt verdensbilde, i høy grad fascinerer og motiverer fysikkelevene (se for eksempel Angell, Guttersrud, Henriksen \& Isnes, 2004; Rødseth \& Bungum, 2010). Læreplanen for programfaget Fysikk 2 i norsk videregående skole (årstrinn 13) tilsier at elevene skal arbeide kvalitativt med kvantefysikk og relativitetsteori, og også drøfte erkjennelsesmessige konsekvenser av teorier i dette fagfeltet. Dette gir et godt utgangspunkt for å bygge en grunnleggende forståelse for hvilke prinsipper moderne fysikk bygger på og hvordan disse bryter med klassisk fysikk. Undersøkelser viser imidlertid at fysikklærere opplever disse kompetansemålene som utfordrende (Bungum, Henriksen, Angell, Tellefsen \& Bøe, 2015), siden det kreves andre arbeidsmåter enn dem vi tradisjonelt finner $\mathrm{i}$ fysikkundervisning, hvor elevenes arbeid ofte preges av regneoppgaver med fasitsvar supplert med elevforsøk. Lærerne etterlyser derfor innfallsvinkler som aktiviserer elevene og bidrar til dybde i deres kvalitative forståelse av moderne fysikk.

Den norske læreplanen er ambisiøs; det er få andre land som har læreplaner i fysikk som tar mål av seg at elevene skal kunne forstå kvantefysikkens brudd med klassisk fysikk og hvilke erkjennelsesmessige konsekvenser dette har (Henriksen et al., 2014). Det er derfor lite forskning om elevers forståelse av disse temaene. Studier av universitetsstudenter internasjonalt viser imidlertid at selv om studentene kan opparbeide seg ferdigheter i å behandle problemstillinger i kvantefysikk med et matematisk formelapparat, mangler de ofte grunnleggende forståelse (Pospiech, 2000; Singh, 2008). Forskning fra ulike land viser også at mange fysikkstudenter på universitetsnivå har en fragmentert forståelse og er ikke bevisste på fundamentet kvantefysikk bygger på og hvordan dette bryter med klassisk fysikk (Ayene, Kriek \& Damtie, 2011; Fischler \& Lichtfeldt, 1992; Hadzidaki, 2008). De beholder derfor gjerne sine klassiske eller semi-klassiske forestillinger parallelt med mer tekniske ferdigheter i moderne fysikk.

ReleKvant er et kombinert forsknings- og utviklingsprosjekt som møter disse utfordringene gjennom forskningsbasert utvikling av nettbaserte undervisningsressurser for fysikk i videregående skole. Ressursene skal støtte utvikling av elevenes kvalitative forståelse og filosofiske refleksjoner. ReleKvant tar utgangspunkt i et sosiokulturelt syn på kunnskap og læring, og undervisningsmodulene som utvikles vektlegger således elevenes bruk av skriftlig og muntlig språk gjennom diskusjoner og skriftliggjøring av egen forståelse. 
I denne artikkelen presenterer vi resultater som belyser hvordan bruk av språk kan avdekke elevers forståelse i kvantefysikk og hvilken betydning kvalitative skriftlige og muntlige refleksjoner kan ha for elevenes læring. Vi fokuserer på to helt grunnleggende prinsipper i kvantefysikk: kvantisering (som motsetning til kontinuitet i klassisk fysikk) og bølge-partikkel-dualismen for lys.

Forskningsspørsmålene er:

1. Hvordan forstår fysikkelever prinsippet om kvantisering og bølge-partikkeldualismen for lys i arbeid med ReleKvant-ressurser, og hvordan kan videreutvikling av ressursene i ReleKvant bidra til å styrke elevers forståelse?

2. Hvordan bidrar skriftlige og muntlige refleksjoner i elevenes arbeid med ReleKvant-ressursene til læring?

Selv om forskningsspørsmålene er knyttet opp mot undervisningsmodulene utviklet i ReleKvant-prosjektet, har de en videre relevans ved at prinsippene som benyttes her, kan overføres til fysikkundervisning uavhengig av de konkrete undervisningsmodulene. Elevenes oppfatninger og utfordringer slik de framkommer i resultatene, har også en videre relevans ved at disse trolig også finnes mer generelt.

\section{Det fysikkfaglige grunnlaget}

\section{Kvantisering og bruddet med klassisk fysikk}

I følge læreplanen LK06 skal elevene kunne diskutere kvantefysikkens brudd med klassisk fysikk. For å kunne diskutere disse bruddene, må elevene kjenne grunnlaget for den klassiske fysikken. Først da gir det mening å snakke om hvordan kvantefysikken bryter med dette (Renstrøm, 2011). Grunnlaget for den klassiske fysikken kan gjengis med tre hovedprinsipper: kontinuitet, determinisme og lokal virkelighet. For resultatene presentert i denne artikkelen er bruddet med kontinuitetsprinsippet av spesiell interesse.

Naturfilosofene fra det gamle Hellas og helt fram til Newtons tid mente at alle prosesser i naturen foregår på en kontinuerlig måte: natura non saltum facit - naturen gjør ingen sprang. En bil som øker farten sin, gjør dette gradvis, og en kule som faller mot bakken, vil anta alle mulige avstander til bakken inntil avstanden er null. Men i 1905 publiserte Einstein sin artikkel om lyskvantene (Einstein, 1905) der han skrev: «Fenomener som har med utsendelse eller omdannelse av lys å gjøre, kan bedre forstås ved å anta at lysenergien er fordelt diskontinuerlig i rommet. Når en lysstråle sendes ut fra et punkt, vil energien, i følge den antakelsen som her legges frem, ikke være kontinuerlig fordelt over et stadig større volum, men bestå av et endelig antall lyskvanter som er lokalisert i rommet, og som beveger seg uten å bli delt, og som kun kan absorberes eller sendes ut som hele.» Kvantisering blir derfor sett på som et brudd med den klassiske fysikkens grunnleggende antakelse om at naturen er basert på et kontinuitetsprinsipp. Einsteins beskrivelse av lys som fotoner resulterer $i$ at energien ikke lenger er kontinuerlig fordelt i rommet, men må beskrives i 
diskontinuerlige sprang. Dette overføres til atomene gjennom Bohrs atommodell som angir energinivåene $\mathrm{i}$ atomet som diskontinuerlige. Vi sier at energien er kvantisert.

\section{Bølge-partikkel-dualismen}

Lys kan i fysikken beskrives både som elektromagnetiske bølger og som partikler. Ulike eksperimenter kan frambringe evidens for lys som enten et bølgefenomen eller som partikler. Lysets egenskaper synes altså å være avhengig av hvordan vi måler og hvilke fenomener vi studerer. Dette forunderlige fenomenet kalles bølge-partikkeldualisme, og innebærer at lys kan sies å være både bølger og partikler. I fysikken har man funnet at også partikler på mikronivå, som for eksempel elektroner, viser bølgeegenskaper. I kvantemekanikken beskriver man fenomener på kvantenivå på abstrakte måter med matematikk. Dette gir resultater som stemmer forbløffende med observasjoner, men hvor begrepsapparatet fra klassisk fysikk og fra dagliglivet kommer til kort. Dette gir opphav til et dilemma for undervisning; på den ene siden ønsker vi å konkretisere og visualisere de abstrakte modellene i kvantefysikk, men på den andre siden kan dette føre til at elevene tolker konkretiseringer og visualiseringer for konkret, noe som kan føre til at de ikke bygger en forståelse for hva som er særegent ved kvantefysikken.

\section{Betydningen av språk i læring av fysikk}

Fysikk er et fag hvor virkeligheten i stor grad beskrives med matematikk. Dette er dermed en viktig del også av fysikkfaget i skolen, men faget har også en rekke andre representasjonsformer. Både likninger, grafiske fremstillinger, verbale uttrykk og eksperimenter er sentralt (Angell et al., 2011). Fysikkens språk er således en viktig del av selve faget, og bruk av skriftlig og muntlig språk er essensielt både i selve innlæringsprosessen og for den faglige forståelsen.

Med et sosiokulturelt perspektiv på læring har teoretikere som Vygotskij (se for eksempel Vygotsky, 1978) belyst hvordan læring av begreper skjer i kommunikasjon med andre. Gjennom ulike former for dialoger kan forståelse for faget og dets begreper vokse fram. Engle og Conant (2002) foreslår fire prinsipper som fremmer faglig forståelse og engasjement: 1) problematisering av innhold, 2) gi elevene autoritet, 3) gi elevene ansvar overfor andre, og 4) tilgang til relevante innholdsressurser.

ReleKvant-modulene problematiserer innhold (1) og gir samtidig tilgang til relevante innholdsressurser (4) som kan belyse de aktuelle kompetansemålene. Elevene gis autoritet (2) ved å bli bedt om å skrive inn svar og diskutere med andre elever eller delta i klassediskusjon (3). Diskusjonene gir også elevene ansvar for andre ved at de må lytte til medelevers svar og forholde seg til disse (3). Når samtalene blir tatt opp og sendt til lærer, synes det som at dette ansvaret virker enda sterkere.

Scott, Mortimer og Aguiar (2006) går nærmere inn på kommunikasjonens hensikt i ulike faser av opplæringen. De formulerer to dimensjoner for kommunikasjonsformer. Den ene handler om interaktiv og ikke-interaktiv kommunikasjon, som beskriver i hvilken grad elevene deltar aktivt i kommunikasjonen. Forelesningen er således et eksempel på en ikke-interaktiv kommunikasjonsform. 
Den andre dimensjonen handler om hvorvidt kommunikasjonen er dialogisk eller autoritativ. I en dialogisk kommunikasjon kommer flere syn til uttrykk, mens den autoritative presenterer fagets etablerte kunnskap. En undervisningssituasjon trenger både en autoritativ og en dialogisk kommunikasjon. Det er læreren som sitter med kunnskapen og må bruke en autoritativ kommunikasjon for å sette i gang arbeidet og for å oppsummere hovedlinjene og den korrekte kunnskapen. Elevene på sin side må delta i en dialogisk kommunikasjon for å konstruere mening og sin egen kunnskap.

God undervisning er karakterisert av en gjennomtenkt variasjon mellom ulike kommunikasjonsformer. Noen ganger vil læreren stille spørsmål som krever et «fasitsvar», men i læringsprosessen er det viktig å åpne for at eleven selv kan arbeide seg fram mot en forståelse ved å få konstruktive og ledende tilbakemeldinger uten å bli vurdert (Mortimer \& Scott, 2003).

Selv uten en kunnskapsrik dialogpartner kan bruk av språk være en viktig brikke $\mathrm{i}$ læringsprosessen. Henriksen og Angell (2010) har vist hvordan det å måtte sette ord på uferdige tanker i dialog med hverandre kan bidra til å utvikle en dypere faglig forståelse hos studenter.

\section{Forskningsdesign i ReleKvant-prosjektet}

I ReleKvant utvikles nettbaserte undervisningsressurser hvor bruk av språk i læringsprosessen står sentralt. Metodikken i prosjektet er inspirert av Education Design Research (EDR), der hensikten er å bygge bro mellom forskning og praksis ved å utvikle løsninger som fungerer i undervisningen i klasserommet, samtidig som det utvikles mer generell kunnskap om elevers forståelse og læring innen et spesifikt tema (se for eksempel McKenney \& Reeves, 2012). Sentralt i denne metoden er at undervisningsressurser og metodikk utvikles gjennom flere runder med utprøving og revisjon i samarbeid med praktiserende lærere. Utviklingen av ressursene i ReleKvant er forskningsbasert ved at den tar utgangspunkt i internasjonale forskningsresultater og perspektiver i fysikkdidaktikk, og ved at ressursene forbedres gjennom analyser av elevers responser som avdekker utfordringer og potensial for læring. I sin tur bidrar dette til forskningsresultater med relevans utover de aktuelle undervisningsressursene. Utviklingen gjøres videre i samarbeid mellom fysikkdidaktikere, fysikklærere og fagpersoner innen fysikk, noe som sikrer at ressursene er godt forankret både i praksisfeltet, i fysikk som fagfelt og i perspektiver fra fysikkdidaktikk som forskningsfelt. I tillegg har masterstudenter og lektorstudenter på lavere nivå bidratt til både utvikling og analyse i prosjektet gjennom studentaktiv forskning.

Ressursene som utvikles er nettbaserte undervisningsmoduler i kvantefysikk og relativitetsteori. Begrepet «modul» angir ressurser for et avgrenset tema i faget, og inneholder illustrerte skriftlige framstillinger, animasjoner og simuleringer, videoer, oppgaver og innspill til diskusjoner i grupper og i hel klasse. Omfanget av hver modul varierer, men de fleste av dem er tilpasset et undervisningsforløp på 2-4 undervisningstimer. Modulene er ikke ment å erstatte læreboka eller lærerens undervisning, men er snarere ressurser for lærerens arbeid i klasserommet, for eksempel ved at det legges opp til klasseromsdiskusjoner hvor lærerens rolle er 
sentral. Hver modul går gjennom en prosess med utvikling, utprøving og modifisering $\mathrm{i}$ tre cykler før de ferdigstilles og lanseres for fri bruk for alle fysikklærere.

Innen kvantefysikk har vi (vår 2015) utviklet seks undervisningsmoduler i kvantefysikk. Disse er gitt følgende arbeidstitler:

Modul 1. Behov for en ny fysikk

Modul 2. Fotoelektrisk effekt

Modul 3. Røntgenstråling

Modul 4. Kvantefysikk og filosofi

Modul 5. Heisenbergs uskarphetsrelasjon

Modul 6. Sammenfiltring

(Modulene i denne versjonen er tilgjengelige på nettsiden www.viten.no/Relekvant3)

Modulene dekker læreplanmålene for kvantefysikk i Fysikk 2, og gir også ekstra ressurser for elever og lærere utover det læreplanen krever.

\section{Datainnsamling og analyse}

Utprøvingen av ressursene innebærer datainnsamling $i$ form av forskernes observasjon i klasserommet, innsamling av elevenes skriftlige svar på oppgaver i den digitale plattformen, og opptak av elevdiskusjoner og fokusgruppeintervjuer med elever i etterkant av arbeidet med ReleKvant-modulene. I første utprøving gjorde vi også filmopptak av undervisningen. Dette ble utelatt i senere utprøvinger, da vi fant at det ikke bidro med vesentlig informasjon utover øvrige data. I det følgende beskriver vi mer konkret de metoder for datainnsamling og analyse som er benyttet for å belyse temaet presentert $\mathrm{i}$ denne artikkelen, det vil si hvordan elever oppfatter bølge-partikkel-dualismen og prinsippet om kvantifisering, og hvordan ReleKvant-ressursene kan styrke læring innen disse områdene. I tråd med EDR som metodisk ramme har resultatene en utviklingsdimensjon ved at de stammer fra ulike trinn i prosessen. Vi har brukt data fra tre utprøvinger i sju klasser ved fem ulike skoler. Tre av klassene deltok i utprøving av den første versjonen, mens to klasser deltok i de to påfølgende utprøvingene med modifiserte versjoner av undervisningsressursene.

Datamaterialet for resultatene som beskrives i denne artikkelen, består av elevers individuelle skriftlige svar på utvalgte oppgaver i Modul 1 (Behov for en ny fysikk) og opptak av elevsamtaler i grupper på 2-3 elever. Disse samtalene er del av undervisningsopplegget med den hensikt at elevene skal utfordres i å sette ord på sin forståelse, og diskutere ulike tolkninger av fysikkfaglige problemstillinger kvalitativt. Samtidig genererer samtalene datamateriale i prosjektet ved at elevene gjør opptak av samtalene på sine egne mobiltelefoner og forskerne får tilgang til opptakene med elevenes samtykke. Datamaterialet består av skriftlige responser fra ca. 50 elever per oppgave og ca. 40 diskusjoner sendt inn som lydfiler.

Vi analyserer elevsvar fra følgende tre oppgaver for å belyse forskningsspørsmålene:

1. et åpningsspørsmål om hva elevene tenker at lys er, basert på deres forkunnskaper fra tidligere undervisning i fysikk og naturfag 
2. elevdiskusjon hvor elevene utveksler og diskuterer sine svar på spørsmålet foran

3. elevdiskusjon hvor elevene skal gi eksempler fra sin hverdag på noe som er kvantisert

Analyser er i utgangspunktet gjort induktivt ved utvikling av kategorier basert på elevenes skriftlige svar og diskusjoner, men er også informert av forskningslitteratur på feltet. Koder er utviklet gjennom tematisk koding (Braun \& Clarke, 2006) ved gjennomgang av et avgrenset antall elevresponser, og deretter validert og i noen tilfeller modifisert ved gjennomgang av et større datamateriale fra flere elever. De tematiske kodene betegner elevresponser som har likhetstrekk i hvordan elevene forstår kvantisering og bølge-partikkel-dualisme. Elever kan imidlertid gi uttrykk for ulike tolkninger, og et elevutsagn kan dermed kodes med flere koder. På grunn av dette, og fordi hensikten med studien er å identifisere de ulike typer av forståelse som finnes i elevgruppa snarere enn å tallfeste dem, oppgir vi ikke tallmateriale i presentasjon av resultatene. For å gi et bilde av hvor utbredt de ulike oppfatningene synes å være, gir vi i stedet kvasikvalitative mål for antall elevresponser som favnes av en kode (som for eksempel «noen få») og «fler enn halvparten»).

Med utgangspunkt i elevenes responser i de to første utprøvingene er både undervisningsmaterialet og spørsmålene til elevene endret noe før tredje utprøving. Hva endringene innebærer, er klargjort i presentasjonen av resultatene.

\section{Resultater}

I det følgende beskriver vi hva materialet fra ReleKvant avdekker om elevers forståelse av henholdsvis kvantisering og bølge-partikkel-dualismen for lys. Parallelt med dette viser vi hvordan diskusjonene mellom elever avdekker ulike misoppfatninger, og hvordan dette gir grunnlag for endringer og videreutvikling av modulene og undervisningsmetodikken knyttet til dem.

\section{Elevers forståelse av kvantisering og kontinuitet}

For å illustrere prinsippet med kvantisering hadde den første utgaven av modulen «Behov for en ny fysikk» en animasjon. Denne viste en kloss $\mathrm{i}$ en fjær der den kontinuerlige energiforandringen i klossen som svinger, ble sammenliknet med de kvantiserte (diskrete) verdiene til energien i Bohrs atommodell. Deretter fikk elevene en oppgave som hadde til hensikt å konkretisere begrepet kvantisering ved å knytte an til elevenes hverdag:

Det er mye her $i$ verden som er kvantisert. For eksempel antall hårstrå på hodet. Snakk med en annen elev. Prøv å komme på minst fire ting $i$ deres hverdag som er kvantisert.

Basert på analyser av elevenes diskusjoner har Myhrehagen (2015) i sin masteroppgave tilknyttet ReleKvant-prosjektet utviklet tre kategorier av elevers forståelse av begrepet kvantisering:

\section{Kvantisering som kvantifisering}


2. Kvantisering som inndeling av et sammensatt system

3. Kvantisering som diskontinuitet

En stor andel elever tolket kvantiseringsbegrepet som en form for kvantifisering (Kategori 1). Typiske eksempler er tolkningen av kvantisering som noe som er tellbart:

Det sto for eksempel antall hårstrå på hodet ditt, eller det eller sånn.. hvis sånn du tar det på det nivået så er alt kvantifisert, antall stoler $i$ rommet, antall ben på menneskekroppen, antall fingre på hendene, men du kan også dele opp $i$ celler og $i$ molekyler, atomer.

Men kvante betyr jo pakke, eller på latin, så det er jo egentlig bare det at man skal forstå det, det er liksom noe man teller på en måte.

Noen elever beskrev kvantisering som at noe må ha en heltallig verdi:

Eh, jo, kvantifisering er at, det er jo det som å dele opp $i$ bestemte nivåer, at man $i$ hverdagen for eksempel, så kan man eksemplifisere med antall venner. Du kan ikke ha et halvt antall venner. Man kan ha 1,2,3.. Man kan ta naturlige tall for eksempel da.

Andre tolket det som noe som det ikke er mulig å telle:

E1: ...Eller er det ting vi kanskje ikke klarer å telle.

E2: Kan finne en enhet. Eller, et tall, sånn, hvordan da?

E1: Antall liter vann $i$ havet for eksempel.

E2: $\mathcal{F}$ a, jeg skjønner. Kan jo regne på det.

E1: Sandkorn $i$ Sahara er ikke så lett å finne ut av.

En annen tolkning viste seg å være kvantisering som en konstant eller noe som hadde en fast verdi (vår utheving), for eksempel:

Kontinuerlig betyr at det er veldig mange mulige verdier, at det ikke er bestemt til bare en verdi, mens når noe er kvantifisert så vil det si at det er en fast verdi, for eksempel...vekten på et elektron...

Vann på jorda... Hvis det fordamper, sả kommer det jo ned igjen! Fa, det er alltid like mye vann på jorda.

Kategori 2 favnet en langt mindre andel av elevsvarene. Her ble kvantisering tolket som en inndeling av et sammensatt system. Eksemplet kan anspore en slik tolkning ved at en hårmanke kan ses på som et system av hårstrå. Noen elever var inne på en mursteinsvegg som er kvantisert gjennom de enkelte mursteinene eller vanndråper som er kvantisert gjennom de enkelte vannmolekylene.

Noen få elever presenterte en tolkning av kvantisering som kan sies å være i tråd med slik det blir brukt i kvantefysikken. Disse favnes i kategori 3, kvantisering som diskontinuitet. En elev beskriver det godt ved å bruke en kjetting som illustrasjon på kvantisering av lengde:

Også en kjetting har en minsteverdi på lengde. Fordi lengdene må gå opp $i$ kjettingringenes lengde $i$ motsetning til en tråd som du kan kutte $i$ akkurat den lengden du vil. Så tråden 
blir da et eksempel på noe kontinuerlig når du korter ned lengden, mens en kjetting må liksom gjøre hopp $i$ lengdene, og er derfor ikke kontinuerlig fordi du må forholde deg til kjettingringene. Så derfor er en kjettingring kvantisert, da.

Siden resultatene fra utprøvingene avdekket at mange elever har misoppfatninger om kvantiseringsbegrepet, ble denne delen av modulen endret før tredje utprøving. I den nye versjonen fikk animasjonen med kloss i fjær en modell av energinivåene til hydrogenatomet ved siden av seg (figur 1A). I stedet for å knytte an til elevenes hverdag fokuserer vi her mer på fysikken. Eksemplet med hårstrå på hodet ble fjernet, og en ekstra illustrasjon ble lagt inn (figur 1B). Vi har også inkludert det historiske prinsippet «natura non saltum facit - naturen gjør ingen sprang» og hvordan Einsteins 1905-artikkel om lyskvanter bryter med dette (figur 1C).

Ved at elevene ble oppfordret til å diskutere og sette ord på begrepene kvantisering og kontinuitet, ble det avdekket flere mulige misoppfatninger av et av hovedprinsippene bak kvantefysikken. Lærerne selv var ikke klar over at dette var et komplisert begrep og ble således mer bevisst hvordan begreper som framstår som intuitive for lærerne kan være snubletråder for elevene.

Det bør nevnes at ordene kvantisering og kvantifisering er svært like og krevende å skille for elevene. Enkelte elever brukte begrepet riktig i en fysisk sammenheng, men kalte det «kvantifisering» fordi de semantisk ikke var presise nok. Etter endringen beskrevet ovenfor bruker mange elever fortsatt feil ord, men det kan synes som de har en bedre forståelse av innholdet, noe dette dialogeksempelet viser (sitater tatt fra start av samtalen):

E1: Fa. Kvantifisering handler om noe som ikke er kontinuerlig.

E2: $M h m$.

E1: Altså man trodde jo først at egenskapene til lys var kontinuerlige, (...) lys på en måte bredde seg likt $i$ rommet på en måte.

E2: $M h m$.

E1: Men Einstein antok at det måtte fordeles diskontinuerlig, altså at lyset, nei hvordan blir det? At energien ble kvantifisert.

E2: fepp.

E1: Det var et brudd med klassisk fysikk fordi man trodde jo tidligere at, ehm, at lys eller at alt var kontinuerlig da.

\section{Elevers forståelse av bølge-partikkel-dualismen for lys}

Modulen «Behov for en ny fysikk» starter med å aktivisere elevers forkunnskaper og tanker om hva lys er. Elevene oppfordres til å skrive inn sine oppfatninger på den digitale plattformen, og deretter diskutere svarene med en medelev.

Basert på analyser av svar fra utprøving i fem av klassene har Gjerland (2015) i sin masteroppgave tilknyttet ReleKvant utviklet fire kategorier av elevers oppfatninger av hva lys er:

1. Lys er elektromagnetiske bølger

2. Lys er partikler

3. Ukritisk dualisme

4. Lys viser både bølge- og partikkelegenskaper 


\section{NITEQ}

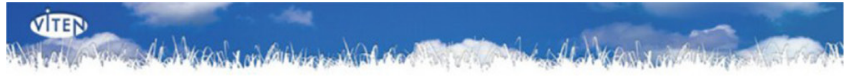

\section{Kvantisering av energi \\ Tenk pả en kloss som \\ henger i en fjær som \\ energien til klossen kan vi \\ beskrive som: \\ $E_{\mathrm{K}}=1 / 2 m v^{2}$}

Klossen kan ha alle mulige verdier for energi. Vi kaller det at energien er

fysikken er det ikke slik. Det kienner du allerede til fra Bohrs atommodell. Her kan atomet bare ha visse energitilstander, ikke alle mulige. Energien til atomet er kvantisert og kan bare ha helt bestemte verdier.

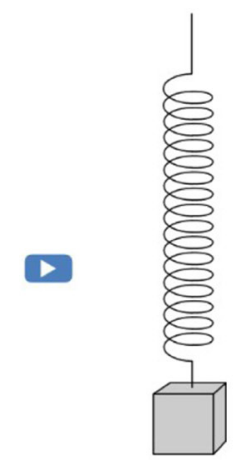

Kontinuerlig energi

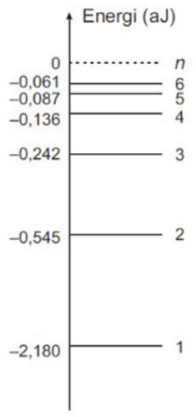

Kvantisert energi

1A: Animasjon av den kontinuerlige energien i en fjærpendel satt opp mot en illustrasjon av den kvantiserte energien i hydrogenatomet.

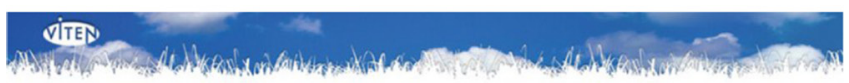

\section{Kvantisert og kontinuerlig}

Noen sider tidligere brukte vi bildet nedenfor. Kanskje du lurte på hvorfor? Ser du noe pá bildet som kan illustrere kvantisering og kontinuitet?

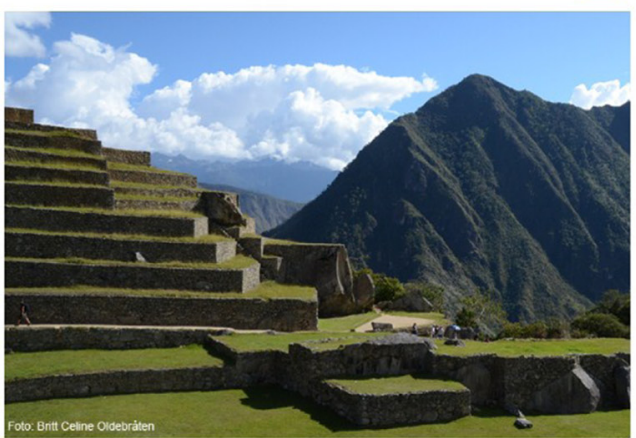

1B: Billedliggjøring av kvantisering og kontinuitet.

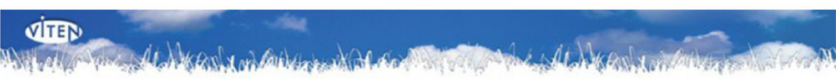

Kvantisering: Diskusjonsoppgave

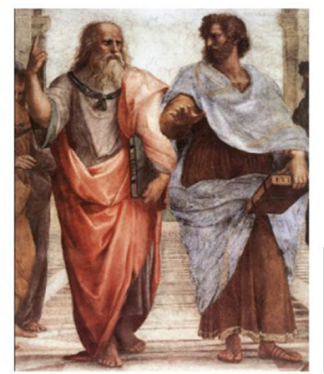

Naturfilosofer fra det gamle Hellas og helt fram til Newtons tid mente at alle prosesser i naturen foregar pa en kontinuerlig
máte: natura non saltum facit - naturen gjør ingen sprang.

Einstein skriver i 1905 i sin artikkel om lyskvantene: Fenomener som har med utsendelse eller omdannelse av lys a giøre, kan bedre forstas ved a anta at lysenergien er fordelt vil energien if fommen Nar en lysstrale utsendes fra et punkt være kontinuerlig fordelt over et stadig større volum, men bestá av et endelig antall lyskvanter som er lokalisert i rommet, og som beveger seg uten a bli delt, og som kun kan absorberes eller sendes ut som hele

Diskusjon 3

Diskuter med en annen elev: Hva betyr kvantisering, og hvordan representerer det et brudd med klassisk fysikk?

1C: Historisk introduksjon til diskusjonsoppgave om kvantisering og kontinuitet.

Figur 1. Skjermbilder fra ReleKvant-modulen «Behov for en ny fysikk». 
Basert på analyser av responser fra ytterligere to klasser har vi supplert disse med en femte kategori:

5. Lys er partikler som går i bølgebevegelser

I kategoriene 1 og 2 gir elevene svar som beskriver lys som henholdsvis enten bølger eller partikler. Et eksempel på elevsvar som beskriver lys som bølger er:

Lys er elektromagnetisk stråling med en bølgelengde mellom 400-700 nm. Lys er bølger som

ikke trenger noe à bevege seg $i$. Lys går $i$ lyshastighet som er $i 3 \cdot 10^{8} \mathrm{~m} / \mathrm{s}$.

(Bølgelengden eleven henviser til, er bølgelengden for den synlige delen av lysspekteret.) Et elevsvar kategorisert som «Lys er partikler» er:

Lys er en strøm av udelelige partikler kalt fotoner

Vi finner også noen få elevsvar som avdekker en misoppfatning tidligere beskrevet av Olsen (2002), nemlig at lys er partikler som beveger seg i bølgebevegelser (kategori 5). Et eksempel på et slikt svar er:

Lys kan sees på som bølger og partikler. Slik jeg har forstått det, er lys partikler med bølgeegenskaper. Altså beveger partiklene seg $i$ bølgebevegelser.

Svaret er interessant ved at det åpner med et korrekt utsagn om at lys kan ses på som bølger og partikler. Først når eleven skal utdype hva dette innebærer, avdekkes misoppfatningen om partikler i bølgebevegelse. Svaret er et eksempel på at elever forsøker å inkorporere ny kunnskap fra moderne fysikk inn i sin forståelse basert på klassisk fysikk som beskrevet av blant andre Ayene et al. (2011).

Den mest interessante kategorien er kategori 3, ukritisk dualisme. Svar i denne kategorien utgjør nesten halvparten av elevsvarene. Et eksempel på svar i denne kategorien er:

Lys er energi $i$ form av små partikler, fotoner. Lyset fär forskjellig farge avhengig av hvilken bølgelengde den har

Eleven starter med å beskrive lys som små partikler kalt fotoner. Dette er korrekt. Videre skriver hun eller han at lyset får forskjellig farge avhengig av bølgelengden. Dette er også korrekt. Imidlertid tar ikke eleven i sitt svar stilling til at det i klassisk forstand er meningsløst å tilordne en bølgelengde til en partikkel. Resultatene tyder på at mange elever har kunnskap om de to modellene for lys uten å legge vekt på at de to modellene ikke er forenelige i klassisk forstand.

I kategori 4 (Lys viser både bølge- og partikkelegenskaper) finner vi elevsvar som tydeligere tar høyde for at vi har med to ulike modeller (beskrivelser) av lys å gjøre, for eksempel:

Lys er fotoner med både bølge- og partikkelegenskaper

Selv om svaret er svært kortfattet, antyder det en forståelse for at lys er «noe») (fotoner) som kan beskrives på to ulike måter. Eleven sier ikke at lys er bølger eller 
partikler, men at det har egenskaper som kan beskrives som bølger eller partikler. Noen elever viser også til det eksperimentelle grunnlaget for begge modeller.

I lydopptakene av elevenes samtaler finner vi at elevene legger fram mye kunnskap om lys, men at diskusjonene ofte blir fragmenterte. Et eksempel på dette er følgende samtale:

E1: Du, hva er egentlig fotoner og lys?

E2: Fa, lys er jo da...

E1: Det er en elektromagnetisk bølge, er det ikke? Som da sendes ut fra et glødende legeme.

E2: $\mathcal{F a}$.

E1: $\mathcal{F a}$ ?

E2: Lys er rett og slett en strøm av fotoner da.

E1: Fa, det kan man si

E2: Fotoner er jo da en... fotoner er jo da veldig små udelelige partikler

Elev E1 beskriver lys som elektromagnetiske bølger, mens E2 henviser til lys som partikler. Elevene synes i dialogen å komme til en slags enighet, til tross for at de henviser til ulike modeller for lys. Utsagnene bygger i liten grad på hverandre i diskusjonen, og synspunkter utfordres ikke.

I videre utvikling av undervisningsmodulene i ReleKvant ønsket vi å løfte fram dilemmaet om at lys beskrives på to måter som ikke er forenelige i klassisk forstand. Vi ønsket at elever med oppfatninger karakterisert som ukritisk dualisme (kategori 3) samt dem som ender opp med en misoppfatning i et forsøk på å forene to klassiske modeller (kategori 5) skulle få en dypere forståelse av at lys beskrives med to modeller fra klassisk fysikk som ikke er forenelige. Vi la derfor inn et oppslag i de digitale ressursene som vist i figur 2 , hvor elevene skal diskutere om lys virkelig kan være både bølge og partikkel på en gang.

Både bølge og partikkel?

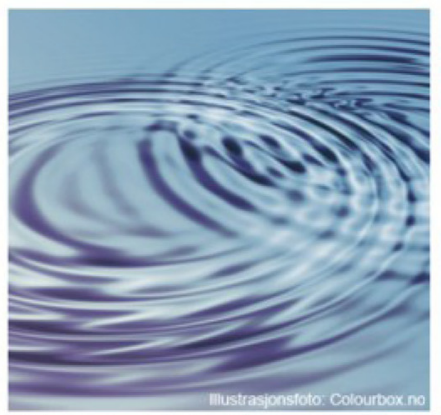

En bølge er en bevegelse som forplanter seg. En bølge har allitid utstrekning; den kan ikke være bare pá et punkt.

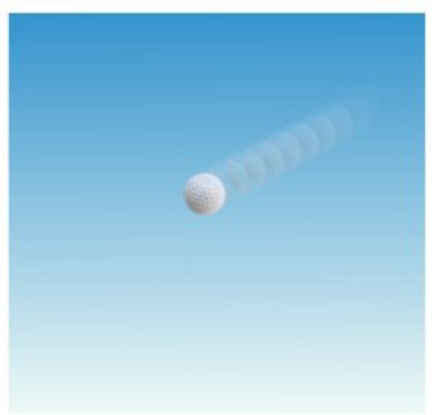

En partikkel er et legeme som er avgrenset til et lite omráde i rommet.

\section{Diskusjon 2}

Diskuter med en annen elev: Gár det an á tenke seg at lys er både bølge og partikkel?

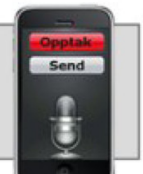

Figur 2. Oppslag i modulen «Behov for en ny fysikk» hvor elevene utfordres til å diskutere om det går an å tenke seg at lys er både bølge og partikkel. 
Oppslaget gjør bruk av makroskopiske modeller, og det klargjør at en bølge må ha utstrekning siden det er en bevegelse som brer seg i rommet, mens en partikkel er karakterisert ved at den nettopp ikke har (betydelig) utstrekning. Følgende opptak fra en elevdiskusjon i utprøving av endrede moduler i en ny fysikk-klasse, viser at dette kan bringe elevene til en dypere forståelse:

E1: feg skrev at lys har bølgenatur og partikkelnatur og lys har ikke masse, men bølgelengde og frekvens.

E2: Bølgelengde og frekvens? Men hvis de oppfører seg som fotoner som er partiklene så er det vel ikke bølgelengde og frekvens som partikler?

E3: Nei.

E4: Nei. Da ville det bare vare bølgenatur, da.

E5: Fa, de har vel ikke bølgenatur heller hvis man ser på det som fotoner. Det er det som problemet da, er det ikke? At det kan oppfore seg fint som begge deler. Og begge deler er gyldig, mens begge deler også motsier seg selv liksom, det er paradoksalt.

I denne dialogen bygger utsagnene på hverandre, i motsetning til dialogen referert ovenfor. Etter at eleven E1 har referert sitt skriftlige svar om hva lys er, tar E2 tak i dette og peker på at noe som er partikler ikke kan ha bølgelengde og frekvens. Sekvensen ender ikke med en klar konklusjon om hva lys er, men den gjør elevene bevisste på at fysikkens beskrivelse av lys med to modeller er paradoksal. Dette er i seg selv en vesentlig innsikt for å forstå hva bølge-partikkel-dualismen innebærer.

\section{Diskusjon og konklusjon}

Resultatene viser at vektleggingen av fysikkelevers bruk av eget språk kaster lys over elevers oppfatninger og avdekker flere utfordringer og misoppfatninger når det gjelder kvantisering og bølge-partikkel-dualismen. Selv om elevene legger for dagen inngående kunnskap om modeller for lys, viser resultatene at mange har et ukritisk forhold til hva dualismen om lys innebærer, og hvordan dette bryter med klassisk fysikk. Om kvantisering, som et helt grunnleggende prinsipp i kvantefysikken, viser resultatene en rekke misoppfatninger blant elevene som trolig ikke ville blitt avdekket gjennom tradisjonell lærerstyrt klasseromsundervisning. Dette viser at begrepet er mer utfordrende enn antatt, og at det bør vektlegges i undervisningen.

Både kvantisering og bølge-partikkel-dualisme er begreper som er utviklet for å beskrive kvantefysiske fenomener. Man kan stille seg spørsmålet om slike begreper er mulige å forstå ut fra elevenes hverdag i en makroskopisk verden og uten det matematiske grunnlaget som kvantefysikken er bygget over. Elevenes responser og diskusjoner viser at det er mulig å kunne snakke om kvantefysikk med et hverdagsspråk på en presis måte, og at dette hverdagsspråket også kan bidra til å avsløre misoppfatninger.

De relativt åpne spørsmålene i ReleKvant synes å bidra til få fram elevers oppfatninger i større grad enn hva man vanligvis får fra mer konsise spørsmål og oppgaver som er vanlige $\mathrm{i}$ undervisningssammenheng. Opptak av diskusjoner mellom elever avdekker at de er kunnskapsrike, men også at de har misoppfatninger som hverken læreren eller forskerne ble oppmerksomme på mens arbeidet 
pågikk i klasserommet. Elevdialogene er imidlertid av varierende kvalitet med tanke på å utfordre og utvikle elevenes forståelse. Eksemplene vi har presentert fra resultater om bølge-partikkel-dualismen, viser hvordan spørsmålsstilling bør peke på et helt konkret og lettfattelig dilemma for å utvikle elevers forstålse giennom samtale. De åpne spørsmålene bidrar altså til å avdekke elevers oppfatninger, mens de mer spesifikke spørsmålene synes å bedre utvikle deres forståelse. Her bør man eksplisitt peke på helt konkrete erkjennelsesmessige dilemmaer i kvantefysikken hvor det ikke finnes opplagte løsninger. Dette gir rom for å skape et «joint workspace» (se Mellingsæter \& Bungum, 2015) i samtalen, som innebærer at utsagn bygger på og utfordrer hverandre og dermed utvikler alle deltagernes forståelse. På den måten kan elevene bli mer bevisste på bruddene med klassisk fysikk og utvikle sin kvalitative forståelse av grunnleggende prinsipper i kvantefysikken, noe som vektlegges i forskningslitteraturen (for eksempel Ayene, et al., 2011; Fischler \& Lichtfeldt, 1992; Hadzidaki, 2008; Pospiech, 2000).

Et opplagt dilemma med tanke på læring er at lærerens stemme mangler i dialogene, til tross for at ressursene er utviklet med tanke på at læreren fortsatt skal undervise og ikke overlate elevene til nettbaserte ressurser. Elevenes dialoger i arbeid med ressursene er nyttige med tanke på at elevene skal sette ord på egne tanker, men de blir i liten grad utfordret på faglig grunnlag. Samtalen mangler således den autoritative siden av gode undervisningsdialoger som beskrevet av Scott et. al (2006). Gjennom observasjoner i klasserommet og samtaler med lærere er det åpenbart at dette dilemmaet oppstår fordi elevgruppene arbeider i ulikt tempo. Læreren ønsker ikke å avbryte elever som arbeider konsentrert med stoff som engasjerer dem for å starte en felles diskusjon, og de har heller ikke mulighet til å følge opp alle gruppene på kritiske punkter der det hadde vært av verdi for elevenes kunnskapsutvikling. Samtidig viser skriftlige og muntlige elevresponser at elevene åpenbart ville hatt nytte av faglige innspill og korreksjoner fra læreren - også der de selv ikke ser dette behovet og ber om hjelp. Dette er et viktig moment å ta hensyn til for videreutvikling av undervisningsressursene, lærerveiledninger i ReleKvant og generelt for undervisning som gjør bruk av elevdialoger. Analysen har avdekket noen kritiske punkter knyttet til den faglige forståelsen hos elevene, der læreren bør være mindre tilbakeholden med å gå inn med en autoritativ kommunikasjonsform og avbryte elevenes arbeid. Disse kritiske punktene er betydningen av kvantisering som begrep og hvordan det er forskjellig fra kvantifisering, og hvordan bølge-partikkel-dualismen innebærer to modeller som i klassisk forstand er uforenelige. Med kunnskap om dette og variert bruk av diskusjoner i klasserommet kan læreren støtte opp om elevenes kunnskapsbygging i kvantefysikk.

\section{Biografi}

Berit Bungum, er professor i realfagdidaktikk ved Skolelaboratoriet for matematikk, naturfag og teknologi ved NTNU. Hun arbeider med kompetanseheving for lærere i realfag og utvikling av undervisningsressurser i naturfag, fysikk og teknologi for grunnskole og videregående skole. Hennes forskning er innen undervisning $\mathrm{i}$ teknologi og moderne fysikk. 


\section{Berit Bungum og Cathrine Wahlstrøm Tellefsen}

Cathrine Wahlstrøm Tellefsen, er førstelektor ved Det matematisk-naturvitenskapelige fakultet, Universitetet $\mathrm{i}$ Oslo, der hun er ansvarlig for lektorutdanningen. Hun har arbeidet i mange år som fysikk- og matematikklærer i videregående skole og er lærebokforfatter i fysikk og naturfag. Hun har også undervist i fysikk ved UiO og er engasjert i utvikling av utdanningskvalitet ved fakultetet.

\section{Referanser}

Angell, C., Bungum, B., Henriksen, E. K., Kolstø, S. D., Persson, J. \& Renstrøm, R. (2011). Fysikkdidaktikk. Kristiansand: Høyskoleforlaget.

Angell, C., Guttersrud, Ø., Henriksen, E. K. \& Isnes, A. (2004). Physics: Frightful, but fun. Pupils’ and teachers' views of physics and physics teaching. Science Education, 88(5), 683-706.

Ayene, M., Kriek, J. \& Damtie, B. (2011). Wave-particle duality and uncertainty principle: Phenomenographic categories of description of tertiary physics students' depictions. Physical Review Special Topics - Physics Education Research, 7(2), 020113-1-0201131-3.

Braun, V. \& Clarke, V. (2006). Using thematic analysis in psychology. Qualitative Research in Psychology, 3(2), 77-101.

Bungum, B., Henriksen, E. K., Angell, C., Tellefsen, C. W. \& Bøe, M. V. (2015). ReleQuant - Improving teaching and learning in quantum physics through educational design research. NorDiNa, 11(2), 153-168.

Engle, R. A. \& Conant, F. R. (2002). Guiding Principles for Fostering Productive Disciplinary Engagement: Explaining an Emergent Argument in a Community of Learners Classroom. Cognition and Instruction, 20(4), 399-483. DOI: 10.1207/s1532690xci2004_1.

Fischler, H. R. \& Lichtfeldt, M. (1992). Modern Physics and Students Conceptions. International fournal of Science Education, 14(2), 181-190.

Gjerland, M. (2015). Elevers oppfatning om lys og bølge/partikkel-dualismen. Masteroppgave, Norges TekniskNaturvitenskapelige Universitet, Trondheim.

Hadzidaki, P. (2008). 'Quantum Mechanics' and 'Scientific Explanation' An Explanatory Strategy Aiming at Providing 'Understanding'. Science E Education, 17(1), 49-73. DOI: 10.1007/s11191-006-9052-8.

Henriksen, E. K. \& Angell, C. (2010). The role of 'talking physics' in an undergraduate physics class using an electronic audience response system. Physics Education, 45(3), 278-284.

Henriksen, E. K. B., Bungum, B., Angell, C., Tellefsen, C. W., Frågåt, T. \& Bøe, M. V. (2014). Relativity, quantum physics and philosophy in the upper secondary curriculum: challenges, opportunities and proposed approaches. Physics Education, 49(6), 678.

McKenney, S. \& Reeves, T. C. (2012). Conducting Educational Design Research. London: Routledge.

Mellingsæter, M. S. \& Bungum, B. (2015). Students' use of the interactive whiteboard during physics group work. European fournal of Engineering Education, 40(2), 115-127.

Mortimer, E. F. \& Scott, P. H. (2003). Meaning Making in Secondary Science Classrooms. Maidenhead, Philadelphia: Open University Press.

Myhrehagen, H. V. (2015). Fysikkelevers forståelse av kvantefysikkens erkjennelsesmessige sider og dens prinsippielle brudd med klassisk fysikk. Masteroppgave. Norges teknisk-naturvitenskapelige universitet, Trondheim.

Olsen, R. V. (2002). Introducing quantum mechanics in the upper secondary school: A study in Norway. International Fournal of Science Education, 24(6), 565-574. DOI: 10.1080/09500690110073982.

Pospiech, G. (2000). Uncertainty and complementarity: the heart of quantum physics. Physics Education, 35(6), 393.

Renstrøm, R. (2011). Kvantefysikkens utvikling ifysikklcerebøker, vitenskapshistorien og undervisning. Universitetet i Oslo, Oslo. Hentet fra http://urn.nb.no/URN:NBN:no-30602

Rødseth, S. \& Bungum, B. (2010). Hva inspirerer til fysikkstudier? En undersøkelse av begynnerstudenter på fysikk. NorDiNa, 6(1), 3-15.

Scott, P. H., Mortimer, E. F. \& Aguiar, O. G. (2006). The tension between authoritative and dialogic discourse: A fundamental characteristic of meaning making interactions in high school science lessons. Science Education, 90(4), 605-631. DOI: 10.1002/sce.20131.

Singh, C. (2008). Interactive learning tutorials on quantum mechanics. American fournal of Physics, 76(4), 400-405.

Vygotsky, L. S. (1978). Mind in Society. The Sevelopment of Higher Psychological Processes. Cambridge MA: Harvard University Press. 